\title{
Politics, Identity and Jamaican Music
}

\author{
Rachelle Sanicharan \\ University of Toronto \\ FAS Canadian Studies Specialist
}

\section{A B S T R A C T}

Music in Jamaica has a long history that is very much intertwined with religious, social, and political factors. As the development of reggae music grew, it became increasingly popular in relation to politics and social issues. This research examines the development of reggae and dancehall music in Jamaica in relation with politics and identity. In turn, this research seeks to present the importance of Jamaican music as a voice for Jamaican people - an accurate presentation of their experiences and their beliefs.

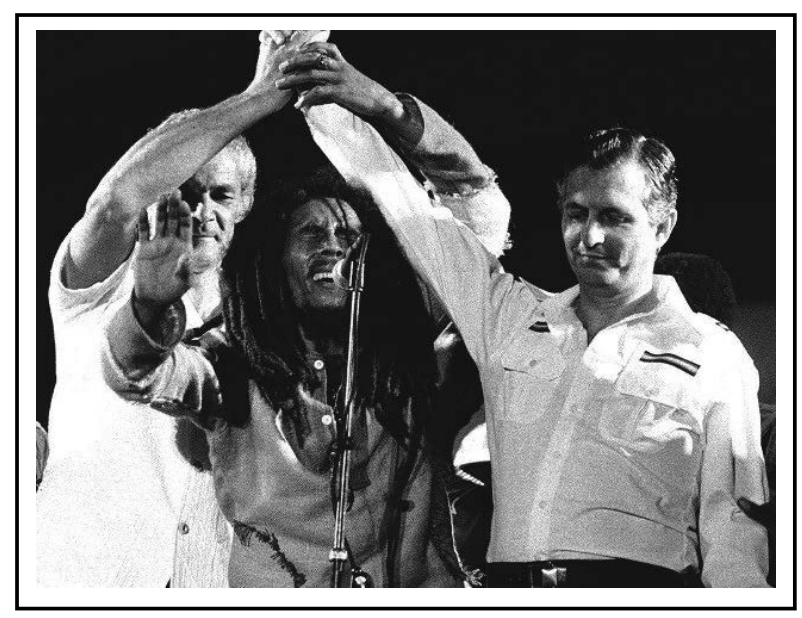

Keywords: Reggae, Dancehall, Jamaican Music, Jamaican Politics, Jamaican Identity

\section{$\mathrm{B} \mathrm{I} \mathrm{O}$}

Rachelle is a fourth-year student as a Canadian Studies Specialist at St. Michael's College University of Toronto. She is an Indo-Guyanese Canadian woman who has a particular interest in researching, recording, and preserving her Indo-Caribbean culture by constantly engaging with Caribbean communities, especially through the non-profit organization that she volunteers with called, Brown Gyal Diary. Brown Gyal Diary's mission is to create a space primarily for Indo-Caribbean women to share their experiences and histories to create recognition and to preserve our culture. Her inspiration towards engaging in Caribbean based work, is mostly linked to her love for family. 
Music in Jamaica has a long history that is very much intertwined with religious, social, and political factors. As the development of reggae music grew, it became increasingly popular in relation to politics and social issues. This research examines the development of reggae and dancehall music in Jamaica in relation with politics and identity. In turn, this research seeks to present the importance of Jamaican music as a voice for Jamaican people — an accurate presentation of their experiences and their beliefs. In order to do so, I will first briefly examine Jamaica's political history, the different factors that lead to Jamaica's independence, and the distinct differentiation between economic classes in Jamaica.

This paper will not go into detail about Jamaica's long history of discovery, the slave trade, and the general settlement period. Instead it focuses on Jamaica in the early 20th Century when Jamaica's political participation began to significantly develop. Throughout the 1930s, Jamaica and Jamaican peoples faced many hardships that involved slow-moving political advancement, economic depression, falling sugar prices, and the ruin of the banana industry due to Panama's industry disease, unemployment, and rising population growth. ${ }^{1}$ Due to these hardships, as well as a lack of voting rights, riots and violence began to tear through the streets of Jamaica. From these riots and violent acts came the emergence of two labour unions and two political parties. Norman Manley founded the National Workers' Union and the People's National Party in 1938 while Sir Alexander Bustamante founded Bustamante Industrial Trade Union and the Jamaica Labour Party in 1943. Norman Manley and the People's National Party (PNP), reflected the interests of the urban petty bourgeoisie, middle peasants and small traders. ${ }^{2}$ Whereas Sir Alexander Bustamante and the Jamaica Labour Party (JLP) reflected the working class, with majority of that class living on the borderline of wag labour and peasant small-holding. ${ }^{3}$

Collectively, Norman Manley and Sir Alexander Bustamante, are credited for moving Jamaica towards self-government. The first general election took place in December 1944 under Universal Adult Suffrage, with the JLP winning 22 out of the 32 seats. Jamaica was one of ten other Caribbean states who formed the Federation of the West Indies, in 1958, but Jamaicans opposed the idea in 1961, abandoning the Federation in order to be a self-governed nation. Almost 20 years later, Jamaica officially gained its independence from Britain on August 6, 1962 with Sir Alexander Bustamante as the country's first Prime Minister. At the time, Jamaica's economy was booming, bauxite was in demand, tourism was gaining popularity, and there was a banana revival. ${ }^{4}$ By 1969 ,

1 “The History of Jamaica.” Jamaica Information Service. Accessed 2021. https://jis.gov.jm/information/jamaican-history/.

2 Ambursley, Fitzroy. "Fitzroy Ambursley, Jamaica: The Demise OF 'Democratic SOCIALISM', NLR I/128, July-August 1981." New Left Review. Accessed 2021. https://newleftreview.org/issues/i128/articles/fitzroy-ambursley-jamaica-thedemise-of-democratic-socialism.

3 See note 2 above.

4 “The History of Jamaica.” Jamaica Information Service. Accessed 2021. https://jis.gov.jm/information/jamaican-history/.

5 Ambursley, Fitzroy. "Fitzroy Ambursley, Jamaica: The Demise OF 'Democratic SOCIALISM', NLR I/128, July-August 1981.” New Left Review. Accessed 2021. https://newleftreview.org/issues/i128/articles/fitzroy-ambursley-jamaica-thedemise-of-democratic-socialism.

6 Dawes, Kwame. "Sound Systems.” World Policy Journal 35, no. 1 (2018): 35-39. https://doi.org/10.1215/07402775-6894768. 
Michael Manley succeeded his father and became the leader of the National People's Party, going on to win the 1972 general election.

Moving into this new period of leadership, the development and progression of reggae as a form of social and political influence, was popularized. Social protest no longer only took the form of riots but "was also taking the form of cultural and musical expression [allowing] the period [to be the] most intense development of the reggae musical idiom." 5 It is imperative to note that reggae also has an intertwined relation with Rastafarianism. While this paper does not cover the religion and the social factors also influenced the stigmatization of reggae artists, this positionality allowed the genre to become a rallying call for the country's marginalized. In addition to the 1972 elections, the year also marked the beginning of greater recognition of the reggae band The Wailers-later Bob Marley and The Wailers - with their signing of a record deal with Island Records. By the mid-70s, The Wailers had released their second studio album, Natty Dread, which was reflective of the political tensions taking place in Jamaica throughout the 70s. With the increase of violence taking place because of the tension between the People's National Party and Jamaica Labour Party, Bob Marley even spoke of his own experience of army member stopping him on the street the night before Manley was elected, in Rebel Music
(3 O'clock Road Block). "The 1970s saw the use of influential reggae 'political songs', which sang the praises of particular candidates, Natty Dread, was no exception. ${ }^{6}$ In addition to Rebel Music, the album also featured the song, Revolution-which many people believed was Bob Marley's promotion of the People's National Party..

Rising in popularity worldwide, Bob Marley and The Wailers released their third album, Rastaman Vibration, in 1976, featuring the song War. This song similarly demonstrates a plea for political change and freedom from oppression. At this time, Bob Marley was such an influential and controversial figure that the CIA had created a file on him and on December 3, 1976 there was an assassination attempt on his life, injuring him, his wife and his manager prior to the Smile Jamaica concert — which is believed to have been an event in support of the People's National Party? Marley still performed at the show but left Jamaica the day after, seeking safety in England. ${ }^{8}$

For the next few years, violence and political tension continued with the general populace picking sides and being divided. Bob Marley returned to Jamaica in 1978 to play the One Love Peace concert, with the goal of calming tensions prior to an election period that was quite violent. Due to the influence that Bob Marley had, he got Prime Minister Michael Manley and Jamaica Labour

\footnotetext{
7 Oumano, Elena. "Reggae Says No TO 'POLITRICKS.' (Music and Politics IN JAMAICA).” The Free Library. Accessed 2021. http://www.thefreelibrary.com/Reggae+says+no+to $\% 27$ politricks. $\% 27+($ music + and + politics + in + Jamaica)-a019701030.

8 See note 7 above.

9 See note 7 above.

10 Edie, Carlene J. "Domestic Politics and External Relations in Jamaica under Michael Manley, 1972-1980." Studies in Comparative International Development 21, no. 1 (1986): 71-94. https://doi.org/10.1007/bf02717364.

11 See note 10 above. 
Party leader, Edward Seaga, on stage, one standing one both sides of Marley. ${ }^{9}$ While the divisions that had developed over the years was not settled by this moment on stage, it demonstrated that in addition to Marley's influence over fans and the broader marginalized community he and his music exerted influence over those in power, and presents another example of the influence that Reggae has had on politics in Jamaica.

Prime Minister Michael Manley was not re-elected in 1980 due to "the PNP's state expansionist policies and anti-imperialist foreign policies [which] were perceived as threatening to the interests of the local bourgeoisie, international financial institutions and the U.S. government." ${ }^{10}$ This led to the withdrawal of "their capital resources from the government." Furthermore, due to the administration's relationship with Fidel Castro and other European communist countries, Manley, a democratic socialist, strained the relationship of allies like Britain, American and Canada. The economic impacts of doing so were a large factor in why he was not re-elected in 1980 and Jamaica Labour Party leader, Edward Seaga came into power. ${ }^{12}$ These external factors were compounded by the fact that the people whom suffered where promised change by Manley, but got tired of waiting for these changes to be implemented. As stated in Jamaica: The Demise of 'Democratic Socialism,' "there is no way to deny the fact that the ultimate weakness of the PNP was its failure to unite and mobilize the small peasants, farm workers, urban wage earners and casual labourers who compromise the overwhelming social and political majority of Jamaican society." 13

Throughout these political changes, reggae remained the music of the people-relatable to the struggles the general populace faced, it is a music that presents a narrative that is all too familiar. As Dawes stated in, Sound Systems: A new generation of Jamaican musicians is blending dancehall and roots reggae to take on the country's problems, "Reggae represented the dreams and ambitions of poor Jamaicans, and it spoke to them in their own voice," many times in proper English so that audiences globally can understand. ${ }^{14}$ That representation was also influencing politics. In 1996, the release of Buju Banton's song It's Politics Time Again essentially launched electoral campaigns for Prime Minister. After many years of back and forth leadership, a record-breaking murder rate and dire economic conditions, Banton singing, "are you going to vote now, we need love not war" was a rallying call for many. ${ }^{15} \mathrm{As}$ we see the commercialization of reggae music, however, some people began to "reject roots reggae for its contamination by white power, its commercial packaging of original song compositions into albums destined for listeners with the money for a

\footnotetext{
${ }^{12}$ Edie, Carlene J. “Domestic Politics and External Relations in Jamaica under Michael Manley, 1972-1980.” Studies in Comparative International Development 21, no. 1 (1986): 71-94. https://doi.org/10.1007/bf02717364.

13 Ambursley, Fitzroy. "Fitzroy Ambursley, Jamaica: The Demise OF 'Democratic SOCIALISM', NLR I/128, JulyAugust 1981.” New Left Review. Accessed 2021. https://newleftreview.org/issues/i128/articles/fitzroy-ambursley-jamaica -the-demise-of-democratic-socialism.

${ }^{14}$ Dawes, Kwame. "Sound Systems.” World Policy Journal 35, no. 1 (2018): 35-39. https://doi.org/10.1215/074027756894768 .

15 Oumano, Elena. "Reggae Says No TO 'POLITRICKS.' (Music and Politics IN JAMAICA)." The Free Library. Accessed 2021.
} 
home turntable." ${ }^{16}$ This allowed dancehall to gain in popularity much in the same way reggae did decades before - as the voice of the people. Though dancehall was present before the 1980s, we see the influence of dancehall emerge, becoming an important part of Jamaican music, experience and identity. As Dawes states, "when chanting or speaking into the mic, dancehall artists directly address a Patwa speaking Jamaican audience." In this way, dancehall literally became the voice and language of the people.

In 1996, Beenie Man, one of the top dancehall artists of all time, promoted the Ghetto Splash concert, the aim was to bring peace and create unity through music, something that the people of Jamaican respond positively to. ${ }^{18}$ The concert was supposed to mirror Marley's One Love Peace concert, with the political leaders clasping their hands together in a show of unity, but the crowd did not respond well, instead booing the display. ${ }^{19}$ The people of Jamaica saw that political elites were trying to use their love of music and the genre's popularity with the masses to manipulate them. As Oumano states, "the voter appeal of Jamaican music has become increasingly evident to politicians, and they are eagerly wooing the music sector, which until recently, was linked in the politicians' minds to a relatively powerless underclass." 20 "show" of unity from political leaders, "Poor people are fed up/the system shut up." Dancehall music often had controversial, sexual, and violent lyrics, but its approach showed a reality that many people experienced in Jamaica. As Spence states in When Money is not Enough: Reggae, Dancehall, and Policy in Jamaica, "dancehall music is of lower-class origin, emerging largely from Kingston's urban ghettos and encapsulating the value and lifestyles thereof." 21

As dancehall has developed into the $21 \mathrm{st}$ century, we see the emergence of new popular artists and artists rivalries - most notably that of Vybz Kartel and Mavado. Once the protégés of Bounty Killa at the beginning of their careers, in 2006, they began their notorious musical war leading to broader social implications. With Kartel from the working-class town, Portmore (aka Gaza) and Mavado from the poor Kingston neighbourhood, Cassava Piece (aka Gully) a divide that is similar to the East Coast v. West Coast Rap era in the United States. ${ }^{23}$ People had to choose a side, making sure that they didn't cross into Gaza territory if they were Gully, and not going into Gully territory if they were Gaza. Just like that, these two artists represented an identity of people, "Jamaican people, home and abroad alike, were no longer 'reping' their political party or color, their Parish, their social status

\footnotetext{
${ }^{16}$ Frydman, Jason. "Death in the Arena." Small Axe: A Caribbean Journal of Criticism 23, no. 3 (2019): 34-49.

17 Dawes, Kwame. "Sound Systems." World Policy Journal 35, no. 1 (2018): 35-39.

18 Oumano, Elena. "Reggae Says No TO 'POLITRICKS.' (Music and Politics IN JAMAICA).” The Free Library.

${ }^{19}$ See note 18 above.

20 Oumano, Elena. "Reggae Says No TO 'POLITRICKS.' (Music and Politics IN JAMAICA)." The Free Library.

${ }^{21}$ Spence, Kim-Marie. "When Money Is Not ENOUGH: Reggae, DANCEHALL, and Policy in Jamaica." The Journal of Arts Management, Law, and Society 49, no. 1 (2018): 45-60.

${ }^{22}$ Gould-Taylor, Sally. "“Bullets and Badges: Understanding the Relationships between Cultural Commodities and Identity Formation in an Era of Gaza vs. Gully: A Jamaican 'Rural' Ethnography.,"” 2016. http://hdl.handle.net/20.500.12613/1329.

${ }^{23}$ See note 22 above.

${ }^{24}$ See note 22 above.
} 
(uptown vs. downtown) their color (browning vs. black). They were 'reping' their association with Gaza or Gully." 24 Carolyn Cooper, Professor of literary and cultural studies at the University of the West Indies and a popular social commentator on everything to do with dancehall, states, "very rarely do we acknowledge the powerful role of dancehall music as serious social commentary. ${ }^{, 25 ،}$ Gaza' and 'Gully' are now a part of everyday language of Jamaican culture. It's like Jamaica Labour Party and People's National Party. We're accustomed to the tribalization of politics that we carry the either/or mentality even into entertainment." The Gully and Gaza clash is more than just who is your favourite artist, it refers to economic and social standing, it refers to how people identify themselves, as Cooper stated, "Like it or not, the real war is not between the Gully and the Gaza. It's between the 'have-nots' and the 'have-gots'. 27

Efforts to move passed this divide is evident in the roots revival reggae which has allowed for a combination of both conscious reggae, dancehall and some Hip-Hop influences. Artists like Damian "Jr. Gong" Marley, Chronixx, and Protoje, are all a part of this revival, however many of these artists have a deeper connection to the music industry. "Jamaican music has historically been associated with the revolutionary power of the lower classes, yet for the most part, the roots-revival artists as middle-class young people who come from a musical lineage." Damian "Jr. Gong" Marley is the youngest son of Bob Marley, Protoje is the son of 1970s reggae singer Lorna Bennett and a father who was a Calypso singer, and Chronixx who was named after his father, Chronicle, a reggae enthusiast. ${ }^{29}$ Even with these conscious reggae artists making music that is reminiscent and influenced by past reggae music, sometimes referring to politics and economic status, "it is clear that dancehall remains the music of the 'underprivileged' as its practitioners tend to speak on behalf of the poor and oppressed - though not always for purposes of political resistance." how both dancehall and reggae have deeper connections to the people of Jamaica, rather than just being music that is enjoyed or even "politics" music, it is also reflective of varying identities of Jamaica.

Jamaican music involves so much more than simple lyrics and musical arrangement. Reggae and dancehall have influenced historical and contemporary Jamaican politics. The music also allows for recognition and acknowledgment of similar experiences and beliefs. In this way, Jamaican music often functions "As a site for 'the repair of cultural injuries" - an opportunity to heal and unite the people. ${ }^{31}$ Similarly, reggae and dancehall are both significant when discussing identity and speaking about

\footnotetext{
${ }^{25}$ Cooper, Carolyn. “One Love on Gaza Street.” The Jamaica Gleaner, November 2009.

https://mobile.jamaica-gleaner.com/20091122/cleisure/cleisure3.ph

${ }^{26}$ See note 25 above.

27 See note 25 above.

28 Dawes, Kwame. "Sound Systems." World Policy Journal 35, no. 1 (2018): 35-39.

https://doi.org/10.1215/07402775-6894768.

29 See note 28 above.

30 See note 28 above.
} 
social and economic hardships, "It is growing increasingly clear that no matter how acidly Jamaican politicians try to exploit their nation's music, reggae is better suited to the rush of revolutionary blood than to reinforcing an inequitable status quo.",32 By highlighting trends in its development, this research has demonstrated the ways in which music in Jamaica has had a long history that is very much intertwined with social and political factors.

\footnotetext{
${ }^{31}$ Mann, Larisa Kingston. "White Faces in Intimate SPACES: Jamaican Popular Music in Global Circulation.” Communication, Culture \& Critique 9, no. 2 (2015): 266-83. https://doi.org/10.1111/cccr.12106.

32 Oumano, Elena. "Reggae Says No TO 'POLITRICKS.' (Music and Politics IN JAMAICA).” The Free Library. Accessed 2021.
} 


\section{Works Cited}

Ambursley, Fitzroy. "Fitzroy Ambursley, Jamaica: The Demise OF 'Democratic SOCIALISM', NLR I/128, July-August 1981.” New Left Review. Accessed 2021. https://newleftreview.org/issues/i128/articles/fitzroy-ambursley-jamaica-thedemise-of-democratic-socialism.

“Bob Marley.” Biography.com. A\&E Networks Television, May 6, 2021. http://www.biography.com/musician/bob-marley.

Cooper, Carolyn. "One Love on Gaza Street.” The Jamaica Gleaner, November 2009. https://mobile.jamaica-gleaner.com/20091122/cleisure/cleisure3.php.

Dawes, Kwame. "Sound Systems." World Policy Journal 35, no. 1 (2018): 35-39. https://doi.org/10.1215/07402775-6894768.

Edie, Carlene J. "Domestic Politics and External Relations in Jamaica under Michael Manley, 1972-1980." Studies in Comparative International Development 21, no. 1 (1986): 71-94. https://doi.org/10.1007/bf02717364.

Frydman, Jason. "Death in the Arena." Small Axe: A Caribbean Journal of Criticism 23, no. 3 (2019): 34-49. https://doi.org/10.1215/07990537-7912310.

Gould-Taylor, Sally. "'Bullets and Badges: Understanding the Relationships between Cultural Commodities and Identity Formation in an Era of Gaza vs. Gully: A Jamaican 'Rural' Ethnography.,"” 2016. http://hdl.handle.net/20.500.12613/1329.

“The History of Jamaica.” Jamaica Information Service. Accessed 2021. https://jis.gov.jm/information/jamaican-history/.

Hope, Donna. "Inna Di Dancehall: Popular Culture and the Politics of Identity in Jamaica." Canadian Journal of Latin American and Caribbean Studies / Revue Canadienne Des Études Latino-Américaines Et Caraïbe 32, no. 64 (2007): 228-30.

Mann, Larisa Kingston. "White Faces in Intimate SPACES: Jamaican Popular Music in Global Circulation." Communication, Culture \& Critique 9, no. 2 (2015): 266-83. https://doi.org/10.1111/cccr.12106.

Nixon, Angelique V. "Blackness, Resistance and Consciousness in Dancehall Culture." Black Renaissance 9, no. 2 (Fall, 2010): 190-199,250. http://myaccess.library.utoronto.ca/login?qurl=https $\% 3 \mathrm{~A} \% 2 \mathrm{~F} \% 2 \mathrm{Fwww}$. proquest. com $\% 2$ Fscholarly-journals\%2Fblacknessresistance-consciousnessdancehall $\% 2 \mathrm{~F}$ docview\%2F365912181\%2Fse2\%3Faccountid\%3D14771.

Oumano, Elena. 'Reggae Says No TO 'POLITRICKS.' (Music and Politics IN JAMAICA)." The Free Library. Accessed 2021.

http://www.thefreelibrary.com/Reggae+says+no+to+\%27politricks. $\% 27+$ (music+and+politics+in+Jamaica)-a019701030.

Spence, Kim-Marie. "When Money Is Not ENOUGH: Reggae, DANCEHALL, and Policy in Jamaica." The Journal of Arts Management, Law, and Society 49, no. 1 (2018): 45-60. https://doi.org/10.1080/10632921.2018.1528191.

Vilanova, John. 'Kingston Be Wise': Jamaica's Reggae Revival, Musical Livity, and Troubling Temporality in the Modern Global Music Industry." International Journal of Communication, 2019.

"At the Crossroads -- Looking for Meaning in Jamaican Dancehall Culture: A Reply." Small Axe 11, no. 1 (2006): 193-204. https://doi.org/10.1353/smx.2006.0031. 